\title{
FEM SIMULATION FOR IMPROVED GRINDING WHEELS
}

\author{
LUKOVICS, I. \& BILEK, O.
}

Abstract: Article deals with behaviour of the grinding wheels within rotation. The shape dependences of the grinding wheels on the physical and mechanical properties are investigated. State of stress simulation was prepared in the FEM solver Cosmos DesignStar. Moreover, results of high-speed grinding are shown in relation to the technological conditions upon the output grinding parameters.

Key words: FEM, Grinding, Critical Velocities, Simulation, Grinding Wheels
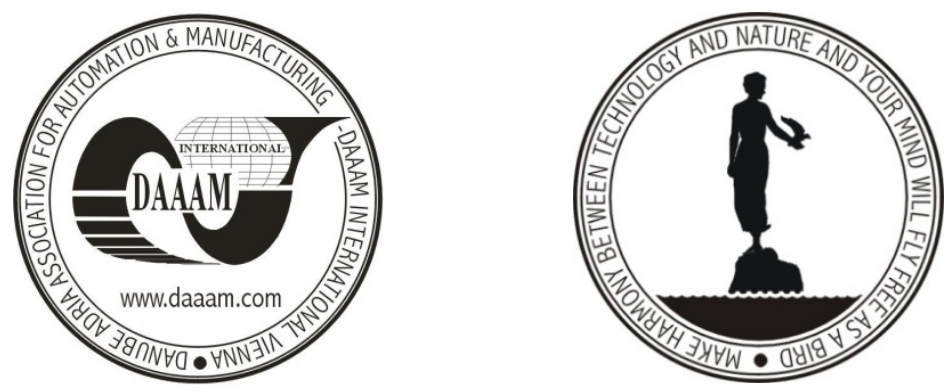

Authors' data: Lukovics, I[mrich]; Prof. Bilek, O[ndrej], Tomas Bata University in Zlin, Nam.TGM 5555, 76001, Zlin, CZ, lukovics@ft.utb.cz, bilek@ft.utb.cz

This Publication has to be referred as: Lukovics, I[mrich] \& Bilek, O[ndrej] (2008). FEM Simulation for Improved Grinding Wheels, Chapter 36 in DAAAM International Scientific Book 2008, pp. 425-432, B. Katalinic (Ed.), Published by DAAAM International, ISBN 978-3-901509-66-7, ISSN 1726-9687, Vienna, Austria DOI: $10.2507 /$ daaam.scibook.2008.36 